\title{
Kondisi Tempat Pemotongan Hewan Bandar Buat Sebagai Penyangga Rumah Pemotongan Hewan (Rph) Kota Padang
}

\section{The Bandar Buat Slaughter House Performances as A Contributor for Slaughter Houses in Padang, West Sumatera}

\author{
Khasrad, J. Hellyward dan A.D. Yuni \\ Fakultas Peternakan Universitas Andalas Padang \\ Kampus Unand Limau Manis Padang, 25163 \\ (Diterima: 12 Desember 2011; Disetujui: 16 Februari 2012)
}

\begin{abstract}
The research observed the activities of Bandar Buat Slaughter house that used a survey method. There were primary data and secondary data. In general, the result of the research showed that it did not run yet as like as standard of slaughter house refer to Peraturan Mentri Pertanian Nomor 13/Permentan/OT.140/1/2010. Furthermore, there were 147 slaughters for one month surveyed. Buffalo slauhgters were the highest proportion about $48.97 \%$. The most percentage of slaughting was the cattle from Solok around $55.72 \%$. The percentage of female cattles slaughting were 52,38\% and the male cattles slaughting were $47,61 \%$.
\end{abstract}

Keywords : Slaughter House, cattle, breed

\section{PENDAHULUAN}

Pangan yang bernilai gizi tinggi sangat dibutuhkan untuk menghasilkan generasi yang cerdas dan sehat. Untuk memenuhi kebutuhan gizi tersebut pangan hewani sangat memegang peranan penting. Saat ini ada kecenderungan permintaan protein hewani terutama daging sapi setiap tahunnya selalu meningkat. Peningkatan permintaan terhadap daging sapi tidak dapat diimbangi oleh produksi daging dalam negeri, namun untuk memenuhinya pemerintah terpaksa membuka kran impor sapi dan daging dari luar negeri. Menurut Ilham dkk. (2002) permintaan daging dalam negeri untuk periode $2000-2010$ mengalami peningkatan sebesar $5 \%$ per tahun, sedangkan penawaran daging domestic diperkirakan mengalami penurunan dengan laju - 0,13\% per tahun. Dengan demikian terjadi kesenjangan yang semakin lebar antara permintaan dan penawaran (Setiyono dkk. 2007).

Untuk itu pemerintah perlu mempersiapkan sarana dan prasarana agar masyarakat bisa mendapatkan daging yang aman, sehat, utuh dan halal. Apalagi dengan meningkatnya impor daging tentu jumlah pemotongan akan semakin meningkat juga. Sarana utama yang perlu dipersiapkan dalam penyediaan daging yang berkualitas adalah Rumah Pemotongan Hewan (RPH). Rumah Pemotongan Hewan merupakan suatu bangunan atau kompleks bangunan dengan disain tertentu yang digunakan sebagai tempat memotong hewan selain unggas bagi konsumsi masyarakat luas.

Keberadaan Rumah Pemotongan Hewan sangat diperlukan, agar dalam pelaksanaan pemotongan hewan dapat terjaga dan terkendali dengan baik. Berdasarkan hal tersebut maka pemerintah membangun Rumah Pemotongan Hewan di berbagai daerah di seluruh Indonesia. Rumah Pemotongan Hewan secara resmi di bawah pengawasan Departemen Pertanian, pada dasarnya mempunyai persyaratan, sesuai dengan surat keputusan Mentri Pertanian No.13/Permentan/ OT.140/1/2010, tentang syarat-syarat pemotongan hewan. Pasal 2 dari SK Mentan tersebut menyatakan bahwa Rumah Pemotongan Hewan merupakan unit/ sarana pelayanan masyarakat dalam penyediaan daging sehat. Lebih lanjut pada bab II dari SK Mentan tersebut mengungkapkan mengenai syarat-syarat Rumah Potong Hewan yang dijelaskan lebih rinci pada pasal 3 ayat (a) menyatakan bahwa Rumah Potong Hewan berlokasi di daerah yang tidak menimbulkan 
gangguan atau pencemaran lingkungan misalnya di bagain pinggir kota yang tidak padat penduduknya.

Selain Rumah Potong Hewan, juga terdapat beberapa Tempat Pemotongan Hewan di satu kota dimana tempat pemotongan hewan tersebut juga harus memenuhi standar yang baku sehingga produk yang dihasilkan terjamin mutu dan kualitasnya. Tempat Pemotongan Hewan tersebut merupakan penyangga bagi RPH dalam penyediaan daging yang aman, sehat, utuh dan halal. Semua pihak yang terkait harus mendukung semua program pemerintah tersebut dengan lebih memperhatikan kondisi Tempat Pemotongan Hewan, karena kondisi lingkungan pada Tempat Pemotongan hewan yang baik sangat mempengaruhi proses pemotongan hewan dalam pemeliharaan kesehatan ternak sebelum dipotong dan pencemaran daging serta karkas setelah dipotong.

Walaupun Tempat Pemotongan Hewan hanya sebagai penyangga Rumah Pemotongan Hewan, tetapi persyaratan dan kondisi pemotongan hewan harus sama, sehingga daging yang dihasilkan dari Tempat Pemotongan Hewan tetap terjaga kualitasnya. Namun kenyataannya banyak Tempat Pemotongan Hewan yang masih belum memenuhi syarat dan masih kurang dalam pengawasan terhadap kesehatan ternak serta keamanan daging. Hal ini bisa saja disebabkan oleh minimnya petugas pengawasan dari Dinas Peternakan atau kurangnya pembinaan dari dinas terkait. Berdasarkan pemikiran di atas, maka penulis tertarik untuk melakukan penelitian mengenai Tempat Pemotongan Hewan di Bandar Buat Kota Padang. Tujuan penelitian ini untuk mengetahui kondisi Tempat Pemotongan Hewan, jumlah pemotongan ternak berdasarkan bangsa ternak, jenis kelamin, tingkat umur produktif dan daerah asal ternak yang dipotong pada Tempat Pemotongan Hewan Bandar Buat Kota Padang.

\section{METODE}

Penelitian dilaksanakan di Tempat Pemotongan Hewan Bandar Buat Kota Padang. Penelitian dilaksanakan selama satu bulan, terhadap semua ternak yang dipotong di Tempat Pemotongan Hewan tersebut.

Metode penelitian ini menggunakan metode survey. Data yang digunakan dalam penelitian ini adalah data primer dan data sekunder. Data primer diperoleh dengan mengamati langsung terhadap semua ternak yang dipotong dan data sekunder diperoleh dari instansi terkait dalam penelitian.

Variabel yang diamati dalam penelitian ini adalah :

1. Kondisi Tempat Pemotongan Hewan (TPH) yang mengacu pada Peraturan Menteri Pertanian Nomor 13/Permentan/ OT.140/1/2010 tentang persyaratan rumah potong hewan ruminansia.

2. Data ternak sapi yang di potong di TPH:

a. Jenis ternak yang di potong

b. Jumlah ternak dan jenis kelamin ternak yang di potong

c. Umur ternak sapi di lihat dari keadaaan gigi ternak

d. Asal daerah ternak sapi di datangkan

Pengolahan dan analisa data dari variabel yang diperoleh dihimpun dalam bentuk tabel kemudian dilakukan analisa deskriptif dan analisa komparatif. Analisa deskriptif dilakukan untuk melihat berapa banyak jumlah pemotongan sapi jantan dan betina, melihat umur ternak yang dipotong.. Analisa komparatif dilakukan untuk membandingkan kondisi umum Tempat Pemotongan Hewan dengan Peraturan Menteri Pertanian Nomor 13/Permentan/OT.140/ $1 / 2010$ tentang persyaratan Rumah Potong Hewan.

\section{HASIL DAN PEMBAHASAN}

\section{Kondisi Umum Tempat Pemotongan Hewan}

Tempat Pemotongan Hewan Bandar Buat Kota Padang sudah berdiri sejak tahun 2004. Tempat Pemotongan Hewan ini berlokasi di Koto Lalang Bandar Buat Kecamatan Lubuk Kilangan Kota Padang. Tempat Pemotongan Hewan ini merupakan milik Pemerintah Kota Padang, yakni Dinas Pertanian, Peternakan, Perkebunan dan Kehutanan Kota Padang sebagai penanggung 
jawabnya. Waktu pendirian Rumah Potong Hewan Pada tahun 2004 lokasi memang sangat jauh dari penduduk, tapi seiring berjalannya waktu dengan pertambahan jumlah penduduk di area TPH ini sudah banyak didirikan perumahan-perumahan, ini bertentangan dengan persyaratan lokasi TPH/RPH. Hal ini perlu diwaspadai karena suatu saat dapat menimbulkan masalah dengan penduduk sekitarnya. Rumah Potong Hewan/ Tempat Pemotongan Hewan adalah kompleks bangunan dengan disain tertentu yang digunakan sebagai tempat memotong hewan potong selain unggas bagi konsumsi masyarakat (Purnawarman, 2000).

Tempat Pemotongan Hewan ini berada di kawasan yang padat penduduk sehingga pada suatu saat dikhawatirkan dapat mengganggu kenyamanan penduduk karena polusi udara dan air, serta dapat mengganggu kesehatan penduduk. Lokasi Tempat Pemotongan Hewan ini tidak menimbulkan bau bagi lingkungan sekitar dan sampai saat ini belum ada complain atau keluhan dari masyarakat di sekitar mengenai polusi yang ditimbulkan oleh aktivitas pemotongan hewan. Untuk pencapaian lokasi ini belum ada keluhan dari pemilik ternak, karena lokasi dekat dengan jalam raya.

Bangunan-bangunan yang ada di TPH yang belum terpenuhi sesuai dengan Peraturan Mentri Pertanian Nomor 13/Permen/OT.140/ $1 / 2010$ tentang persyaratan rumah potong hewan ruminansia, diantaranya seperti laboratorim, ruang administrasi, kamar mandi/ WC dan tempat pertemuan. Bagian dari bangunan utama TPH yang sudah terpenuhi adalah tempat penyembelihan hewan, tempat pembersihan dan pencucian daging dan jeroan, tempat penyelesaian proses penyembelihan. Sedangkan yang belum terpenuhi adalah tempat pemeriksaaan kesehatan daging, ruang penempaan kulit dan kaki hewan yang telah disembelih, ruang jeroan dan ruang kepala, hati, jantung dan paru-paru.

Untuk ternak sapi yang dicurigai terserang penyakit yang berbahaya maka di TPH ini disediakan pula tempat mengisolasi hewan agar nantinya tidak memberikan pengaruh terhadap lingkungan sekitarnya.
Untuk proses pengolahan limbah di TPH ini telah disediakan empat buah bak pengendap yang berguna sebagai penampung sementara buangan padat sebelum diangkut atau dibuang ke sungai, hal ini sudah sesuai dengan Manual Kesmavet (1993).

Konstruksi Tempat Pemotongan Hewan terdiri dari ruang yang cukup untuk pelaksanaan proses pemotongan hewan dengan dinding bagian dan lantainya yang tidak dilapisi oleh keramik, untuk atapnya terbuat dari bahan yang layak yakni dari seng, memiliki ventilasi yang cukup yang terbuat dari besi dan penerangan yang cukup baik, penerangan Tempat Pemotongan Hewan ini hanya bersumber dari Listrik. Di tempat pemotongan hewan ini juga tersedia air bersih yang bersumber dari sumur gali yang berjumlah satu buah dan dilengkapi juga dengan satu buah tower air, di tempat pemotongan hewan ini juga terdapat saluran pembuangan limbah.

\section{Jenis Ternak Yang Dipotong}

Berdasarkan hasil penelitian, terdapat beberapa jenis ternak yang dipotong pada Tempat Pemotongan Hewan (TPH) Bandar Buat Kota Padang. Jenis ternak yang dipotong diantaranya Simental, Peranakan Onggole (PO), Brahman, Sapi Pesisir, dan Kerbau. Untuk lebih jelas dapat dilihat pada tabel 1.

Dari Tabel 1 diketahui bahwa jenis ternak yang paling banyak dipotong adalah Kerbau yaitu 48,97\% dan yang paling sedikit Sapi Bali yaitu 2,04\%. Sedangkan ternak sapi yang paling banyak dipotong adalah sapi pesisir atau ternak lokal. Adanya perbedaan jumlah pemotongan dari masing-masing ternak erat sekali kaitannya dengan ketersediaan dan populasi ternak itu sendiri, untuk dijadikan ternak potong di Sumatera Barat. Forres dkk (1975) dalam Khadijah (2005) mengemukakan bahwa bangsa akan mempengaruhi terhadap pertumbuhan dan kondisi tubuh, juga memperngaruhi terhadap kemampuan untuk menghasilkan daging sehingga mengakibatkan perbedaan berat karkas yang dihasilkan. 
Tabel 1. Jenis Ternak yang dipotong di Tempat Pemotongan Hewan (TPH) Bandar Buat selama 1 Bulan

\begin{tabular}{lcc}
\hline Jenis Ternak yang Dipotong & Jumlah (ekor) & Persentase (\%) \\
\hline Simental & 22 & 14,96 \\
Peranakan Ongol (PO) & 12 & 8,16 \\
Brahman & 12 & 8,16 \\
Sapi Pesisir & 26 & 17,68 \\
Bali & 3 & 2,04 \\
Kerbau & 72 & 48,97 \\
\hline Total & 47 & 100 \\
\hline
\end{tabular}

Tabel 2. Pemotongan Ternak Berdasarkan Daerah Asal Ternak

\begin{tabular}{lcc}
\hline Daerah Asal Ternak & Jumlah (ekor) & Persentase $(\%)$ \\
\hline Solok & 82 & 55,78 \\
Pesisir Selatan & 29 & 19,72 \\
Padang & 36 & 24,48 \\
\hline Total & 147 & 100 \\
\hline
\end{tabular}

Tabel 3. Pemotongan Ternak Berdasarkan Jenis Kelamin

\begin{tabular}{lcc}
\hline Jenis Kelamin & Jumlah Pemotongan (ekor) & Persentase (\%) \\
\hline Jantan & 70 & 47,61 \\
Betina & 77 & 52,38 \\
\hline Total & 147 & 100 \\
\hline
\end{tabular}

\section{Daerah Asal Ternak Yang Dipotong}

Daerah asal ternak diantaranya Solok, Pesisir Selatan, dan Padang, untuk lebih jelasnya dapat dilihat pada Tabel 2. Asal ternak yang terbanyak dipotong dari daerah Solok dengan persentase 55,78\% kemudian disusul oleh daerah Padang dengan persenase $24,48 \%$ dan daerah Pesisir Selatan dengan persentase $19,72 \%$.

\section{Jumlah Ternak yang Dipotong Berdasarkan Jenis Kelamin}

Perbandingan jumlah pemotongan ternak berdasarkan jenis kelamin dapat dilihat dari Tabel 3. Dari tabel 3 dapat dilihat tingkat pemotongan hewan betina cukup tinggi dimana mencapai $52,38 \%$, hal ini harus mendapatkan perhatian khusus dari pemerintah karena ini menyangkut ketersedian sapi yang ada di Indonesia. Para toke ternak memilih hewan betina karena tidak seimbangnya antara jumlah populasi ternak dengan permintaan yang ada di pasar saat sekarang ini. Oleh karena itu untuk memenuhi permintaan pasar maka ternak betina banyak yang dipotong.

Santosa (2005) mengemukakan bahwa apabila dipilih jenis kelamin jantan untuk digemukkan, pedet akan mempunyai bobot lahir yang tinggi, pertambahan berat badan yang tinggi dan lama penggemukannya cepat. Dari itu dapat kita ambil kesimpulan bahwasanya ternak jantan lebih mudah untuk digemukkan dari pada ternak betina.

\section{Ternak yang Dipotong Berdasarkan Tingkatan Umur}

Pemotongan ternak berdasarkan umur di TPH Bandar Buat Kota Padang berkisar antara umur 3,5 sampai 5,5 tahun. Untuk lebih 
Tabel 4. Pemotongan Ternak Sapi Berdasarkan Umur

\begin{tabular}{lcccccc}
\hline $\begin{array}{l}\text { Umur } \\
\text { Sapi }\end{array}$ & $\begin{array}{c}\text { Jumlah } \\
\text { Jantan } \\
\text { (ekor) }\end{array}$ & $\begin{array}{c}\text { Persentase } \\
(\%)\end{array}$ & $\begin{array}{c}\text { Jumlah } \\
\text { Betina } \\
(\text { ekor) }\end{array}$ & $\begin{array}{c}\text { Persentase } \\
(\%)\end{array}$ & $\begin{array}{c}\text { Total } \\
\text { Pemotongan }\end{array}$ & $\begin{array}{c}\text { Persentase } \\
(\%)\end{array}$ \\
\hline $3,5-4$ & 30 & $42,85 \%$ & 20 & $25,97 \%$ & 50 & $34,01 \%$ \\
$4,5-5$ & 39 & $55,71 \%$ & 51 & $66,23 \%$ & 90 & $61,22 \%$ \\
$5,5-6$ & 1 & $1,42 \%$ & 6 & $7,79 \%$ & 7 & $4,76 \%$ \\
\hline Total & 70 & $100 \%$ & 77 & $100 \%$ & 147 & $100 \%$ \\
\hline
\end{tabular}

lengkapnya dapat dilihat dalam Tabel 4 . Berdasarkan Tabel 4 dapat diketahui bahwa pemotongan yang terbanyak yaitu pada umur 4,5 sampai 5 tahun sebesar $61,22 \%$ dan yang terkecil 5,5-6 tahun sebesar 4,67\%. Para toke ternak lebih cenderung memilih ternak muda, menurut mereka sapi tua memiliki daging yang keras, hal ini juga dipengaruhi oleh kecendrungan konsumen memilih daging yang dikonsumsi. AKK (2003) menjelaskan bahwa sapi yang sudah tua mutu dagingnya sangat rendah, apalagi bila sapi tersebut dipakai untuk bekerja seperti membajak atau menarik beban. Daging sapi yang sudah tua biasanya berwarna merah tua, serabutnya kasar dan apabila dimasak terasa liat. Sebaliknya sapi yang masih muda (sekitar 1,5-2,5 tahun), dagingnya akan tampak berwarna merah terang, serabutnya halus dan apabila dimasak akan terasa lebih empuk.

Berdasarkan hasil penelitian dapat kita lihat bahwa pemotongan ternak sapi baik jantan maupun betina masih pada umur yang produktif, hal ini disebabkan karena peternak lebih cendrung memelihara ternak pada umur produktif. Untuk menggemukkan dipilih sapi yang berumur satu sampai empat tahun karena sapi yang terlalu muda atau sudah tua kurang menguntungkan, sebab pertumbuhan dan penambahan berat badan relative lebih lambat (Djariah, 1996). Sugeng (1998) menggemukakan bahwa penimbunan lemak terjadi sesudah hewan mencapai kedewasaan tubuh, yakni sesudah pertumbuhan jaringan tulang dan otot selesai, kemudian diikuti pembentukan lemak.

\section{KESIMPULAN}

Berdasarkan hasil penilitian dapat diambil kesimpulan sebagai berikut:

1. Tempat Pemotongan Hewan (TPH) Bandar Buat Kota Padang dalam operasionalnya belum semuanya memenuhi persyaratan syarat teknis Rumah Potong Hewan sesuai dengan Peraturan Mentri Pertanian Nomor 13/Permentan/OT.140/1/2010.

2. Pemotongan ternak di Tempat Pemotongan Hewan Bandar Buat Kota Padang salama 1 bulan berjumlah 147 ekor. Pemotongan ternak yang terbanyak yaitu Kerbau sebanyak 72 ekor $(48,97 \%)$.

3. Pemotongan ternak menurut daerah asal yang terbanyak berasal dari daerah Solok dengan jumlah sebesar 82 ekor $(55,72 \%)$.

4. Pemotongan berdasarkan jenis kelamin terbanyak terdapat pada sapi betina yang berjumlah 77 ekot $(52,38 \%)$ sedangkan pemotongan ternak berdasarkan umur yang paling banyak pada umur 4,5 sampai 5 tahun dengan jumlah 90 ekor $(61,22 \%)$.

\section{DAFTAR PUSTAKA}

Aksi Agrarius Kanisius, 2003. Petunjuk Beternak Sapi Potong Dan Kerja. Kanisius, Yogyakarta

Dinas Peternakan, 2005. Standar Rumah Potong Hewan

Djarijah, A.S. 1996. Usaha Ternak Sapi. Kanisius, Yogyakarta

Ilham, N., S. Hastuti dan I.K. Karyasa. 2002. Pendugaan Parameter dan Elastisitas 
Penawaran dan Permintaan Beberapa Jenis Daging di Indonesia. JAE, 20.

Khadijah, S. 2005. Pendugaan Bobot Karkas Berdasarkan Bobot Hidup Sapi Peranakan Onggole Jantan di Rumah Potong Hewan Mabar Medan. Skripsi. Fakultas Peternakan Universitas Andalas, Padang

Manual Kesmavet, 1993. Pedoman Pembinaan Kesmavet. Direktorat Bina Kesehatan Hewan Direktorat Jendral Peternakan, Departemen Pertanian, Jakarta

Mentri Pertanian Nomor 13/Permentan/OT. 140///2010 tentang persyaratan Rumah Potong Hewan Ruminansia Dan Unit Penanganan Daging (Meat Cutting Plant), Jakarta
Mentri Pertanian RI., 1986. Surat Keputusan No.555/kpts/TN.240./9/1986. Tentang syarat Rumah Potong Hewan dan Usaha Pemotongan Hewan. Mentri Pertanian RI. Jakarta

Purnawarman, T. 2000. Pelatihan Jaminan Keamanan Daging di Rumah Potong Hewan. Fakultas Kedokteran Hewan Institut Pertanian Bogor. Bogor

Santosa, U. 2000. Tata Laksana Pemeliharaan Ternak Sapi. Penebar Swadaya, Jakarta.

Setyono D.J., . Maharani dan W. Rindayanti. 2007. Konsumsi Daging Sapi Segar Konsumen Rumah Tangga di Pasar Tradisional. Med. Pet. 26 (1).

Sugeng, Y. B. 1998. Sapi Potong. Penebar Swadaya, Jakarta 